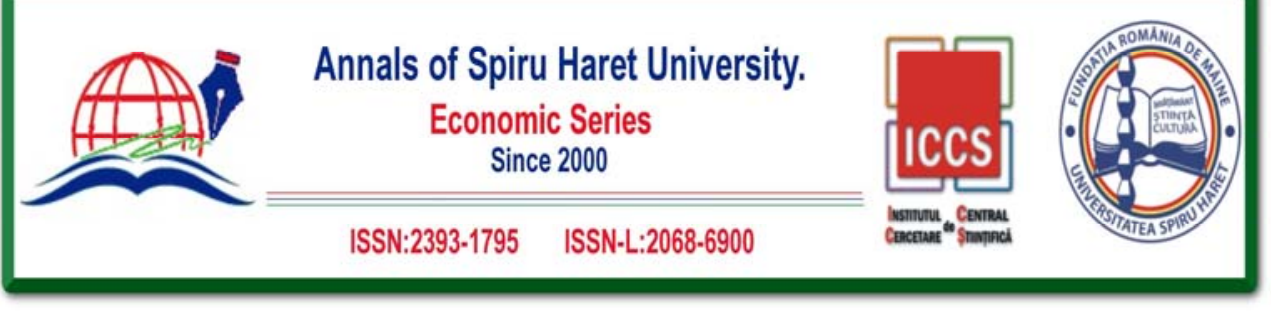

Issue $\mathbf{1} / 2019$

\title{
THE DEVELOPMENT OF MARKETING IN TOURISM INDUSTRY
}

\author{
Bogdan SOFRONOV ${ }^{1}$ \\ ${ }^{1}$ University Politehnica of Bucharest, 313 Splaiul Independenței, \\ Bucharest, 060042, Romania, Email: bogdansofronov@yahoo.com
}

How to cite: SOFRONOV, B. (2019). "The Development of Marketing in Tourism Industry.” Annals of Spiru Haret University. Economic Series, 19(1), 115-125, doi: https://doi.org/10.26458/1917

\begin{abstract}
The purpose of this paper is to show how marketing in developing and changing the tourism industry in the world.

Tourism marketing is the business discipline of attracting visitors to a specific location. Hotels, cities, states, consumer attractions, convention centres and other sites and locations associated with consumer and business travel, all apply basic marketing strategies to specific techniques designed to increase visits.

In the tourism industry, marketing includes determining the unique selling benefit or benefits one area has over its competition. A destination might offer people looking to combine business and pleasure ease of travel to and from the area, ample convention halls and hotels, interesting nightlife, and activities for adult partners and children.

The tourism marketing uses a wide variety of communications strategies and techniques to promote areas and destinations. A convention centre might purchase advertisements in trade magazines for meeting planners and send direct mail materials to corporations that hold events. They might place ads in tennis or golf magazines to attract those consumers. The tourism destinations build websites and place ads in consumer publications read by their target customers. The chambers of commerce are involved in promoting their areas generally and the businesses within their areas specifically. This often includes offering potential visitors packets filled with brochures, discount coupons and other materials.
\end{abstract}




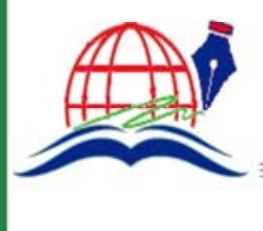

Annals of Spiru Haret University.

Economic Series

Since 2000

ISSN:2393-1795 ISSN-L:2068-6900
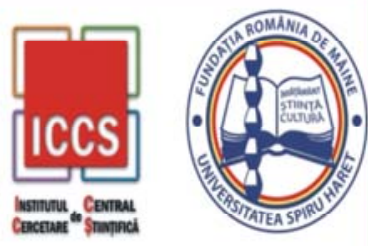

Issue 1/2019

Keywords: development; marketing; tourism; tourism industry; international tourism

JEL Classification: Z30, Z32

\section{Introduction}

Marketing in the tourism industry is defined as the policy promoted by a tourism enterprise which, by constantly exploring the conditions of the tourism market, both present and future, aims to determine the continuous adaptation of its own offer to these conditions in order to optimally satisfy requirements and the realization, on this basis, of a cost-effective economic activity.

Marketing in tourism requires a good knowledge of the exigencies and trends of the market, the orientation of the supply of tourism products according to the size and structure of the demand, the establishment of a price and pricing strategy, a distribution platform, the use of effective tools for promoting the tourism product, estimating sales opportunities by seasonality.

Marketing in the tourism industry include all the measures by which the management of a tourism company can explore the product-market relationships by organizing and directing on their basis all the economic activities that are considered necessary to evaluate the potential customer and transform it into a actual demand for a particular tourism product, as well as its supply to the costumer in order to achieve the expected profit and other objectives set in the development programs of the tourist units.

The tourist market is made from a network of segments, from certain categories of clients with preferences, desires, needs and own reasons. For this reason, the tourism market can be differentiated by many tourism categories to develop suitable marketing strategies.

\section{Literature Review}

My research paper entitled: The development of marketing in tourism industry, is written after I've documented on the basis of the following published articles:

1. "The Relationships among Experiential Marketing, Service Innovation, and Customer Satisfaction - A Case Study of Tourism Factories in Taiwan" written by Tsu-Ming Yeh, Shun-Hsing Chen and Tsen-Fei Chen and published in Journal of Marketing for Sustainable Tourism. 
2. "The Implementation of the Marketing Communication Mix Using Internet Platforms on Turkish Cypriot Hotels" written by Zead M. Alhawamdeh and published in International Journal of Business and Management.

3. "Implementation of Corporate Governance Mechanisms in Tourism" written by Fuad Jabbarov and published in Annals of Spiru Haret University. Economic Series.

4. "Developing Inter-Organizational Relationships with Online Travel Agencies (OTAs) and the Hotel Industry” written by Cherry Huang Yin, Edmund Goh and Rob Law and published in Journal of Travel \& Tourism Marketing.

\section{The Development of Marketing in Tourism Industry}

Every marketing effort should begin with a plan, and tourism marketing is no different. The marketing plan is your road map and details the attractions in your area. It forces you to set a budget on your promotional spending. At the end of each tourism season, you can use your marketing plan to set goals and make changes for the next year. [Chron, 2019]

If revenue at one attraction did not meet expectations, perhaps it needs product development - some upgrades to make it more appealing to visitors - or better advertising. [Chron, 2019]

Tourism marketing can be expensive, particularly if you want to attract national or international tourists. Typical funding sources are state tourism agencies and taxes, including hotel taxes. If there are several tourist attractions in a specific county - or across several neighbouring counties -, the entire area can be marketed to potential visitors as an appealing weeklong destination by combining advertising and other marketing activities. Partnerships can provide tourists with a fuller travel experience. [Chron, 2019]

Marketing in the tourism industry has distinct characteristics from other marketing plans. Because tourists are temporary, they are exposed to an area's goods and services for shorter periods. But tourists are counting on having a good time, so marketers should consider strategies that appeal to the emotions, such as treating kids to a memorable experience. [Chron, 2019]

Tourism-dependent businesses rely on other organizations. One example of leveraging this dependence would be a musical venue offering discount coupons for meals at a nearby restaurant. [Chron, 2019]

Tourism does not only mean travelling to a particular destination but also includes all activities undertaken during the stay. [Gupta \& Mirjha, 2016] 


\section{Issue 1/2019}

Combining tourism with volunteer opportunities is another tourism marketing strategy that appeals to many tourists. Popular both domestically and abroad, such volunteer tourism can range from repairing schools on American Indian reservations to installing water systems in poor communities. [Chron, 2019]

Promoting sustainable tourism efforts also appeals to environmentally conscious travellers. Sustainable tourism emphasizes a balance on tourist activities and the effect it has on its surroundings, such as the environment. Practices include such things as energy-saving upgrades, environmentally friendly products and signs and even limiting the number of visitors to outdoor areas. [Chron, 2019]

In essence, marketing communications is contemporarily a collective terminology used to refer to all the communications functions applied towards successfully marketing a service or product. [Alhawamdeh, 2019]

Tourism industry can also establish promotion mechanisms for marketing and create more opportunities for development through cooperation with local festive and cultural events, horizontal alliances, and resource integration. [Yeh, et al., 2019]

Modern market trends in the world, in the process of constant volatility of market conditions, supply and demand, contribute to the development of certain mechanisms to counter the recession. [Jabbarov, 2018]

Tourism marketing keeps up with the dynamic evolutions and the demands of tourism industry in relation to the diversity of tourism marketing in modern organizations. [Kasemsap, 2015]

Tourism marketing helps tourism product and service providers promote their businesses, brands and destinations. This type of marketing can be quite expensive, particularly if the aim is to attract national or international tourists. So, forming partnerships lowers marketing costs for individual tourism product-providers. [Novelus, 2019]

Tourism is often a part of the leisure activities. In this sense, marketing in tourism is part of a broader activity, called free-time marketing. [Novelus, 2019]

On that note, we think that marketing in tourism has an important role to connect the tourism product-providers in one integrated network. Our tourism marketing strategies and methods are based on relationships between tourism market-operators and the characteristics of the tourism product itself. [Novelus, 2019]

Promoting the global marketing policy of a tourism company, based on optimal efforts, involves a coherent set of action practices, based on specific programs.

Tourism industry goes hand in hand with Digital Marketing. The new generation of travellers no longer just rely on local agencies to help them decide 118 


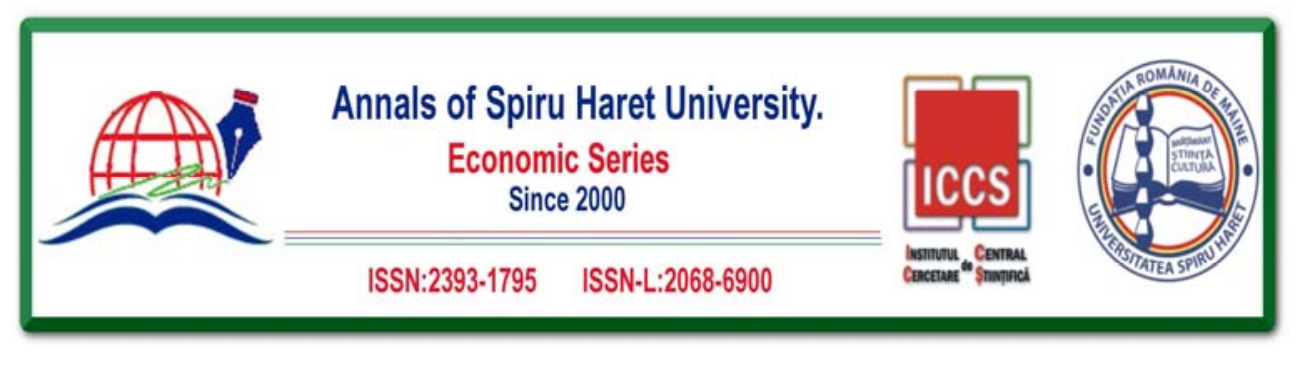

Issue 1/2019

where to go. Gen $\mathrm{Z}$ people are getting inspiration online via various channels including Facebook, YouTube, Instagram and many other travel channels. [Nilead, 2019]

There is no doubt that Digital Marketing is used by so many businesses of different industries and has proven its worth in delivering many more leads to them. And of course, more leads mean more business and more business means more profit. The tourism industry is no different and has adapted well on the realm of digital world to increase their brands' awareness and be able to reach more possible customers as much as they could.[Nilead, 2019]

In the advent of today's digital age, the importance of Digital Marketing for businesses has grown and the travel industry did not let this opportunity slip away. By going online, the travel business agencies can now implement different activities to make them known, reach a lot of people all over the world and tell them exclusive offers and post ads that will make every person watching want to head out and start planning for a getaway. Truly, the influence of Digital Marketing transcends borders which allowed the travel sector to entice people from all over the world of the different places they can visit. [Nilead, 2019]

The tourism industry is undeniably one of the first that was affected as the world migrated to digitalization. The competition was all about coming up with the best strategy and utilizing it to make a successful trip and worthwhile experience to all their patrons. The better they do it, the more loyal patrons they can have and the more the profit increases. But of course, Digital Marketing does not only stop in making sure travellers can have the best pre-trip experience, it also covers the inflight and destination marketing. Digital Marketing is a guide for travellers to get the best of their travel experience. [Nilead, 2019]

A successful Digital Marketing in the Tourism Industry should not just stop in enticing guests to buy travel deals. To create a successful one, you should include the strategy in the three phases of travel so that you can bring your guests back to you and gain their loyalty. Remember, taking good care of your guests is the key to keep them on your side. [Nilead, 2019]

Booking by mobile continues to increase - the customers prefer to self-serve in order to get the information that they need. [TrekkBlog, 2019]

Many businesses have enjoyed great successes by investing in Digital Marketing. Whether you are a ticketing office, a hotel reservation company, a booking company for restaurants and bars or a travel package provider, we assure you that you can make 


\section{Issue 1/2019}

use of Digital Marketing in a way or two. Whether or not you will be successful, all depends on the way you plan and implement your strategy. An experienced Digital Marketing Agency can certainly help you to properly plan and get things up and running, but in the end everything relies on your effort and commitment into making Digital Marketing work for you. To give you an idea of how some travel and tourism agencies are making use of Digital Marketing. [Nilead, 2019]

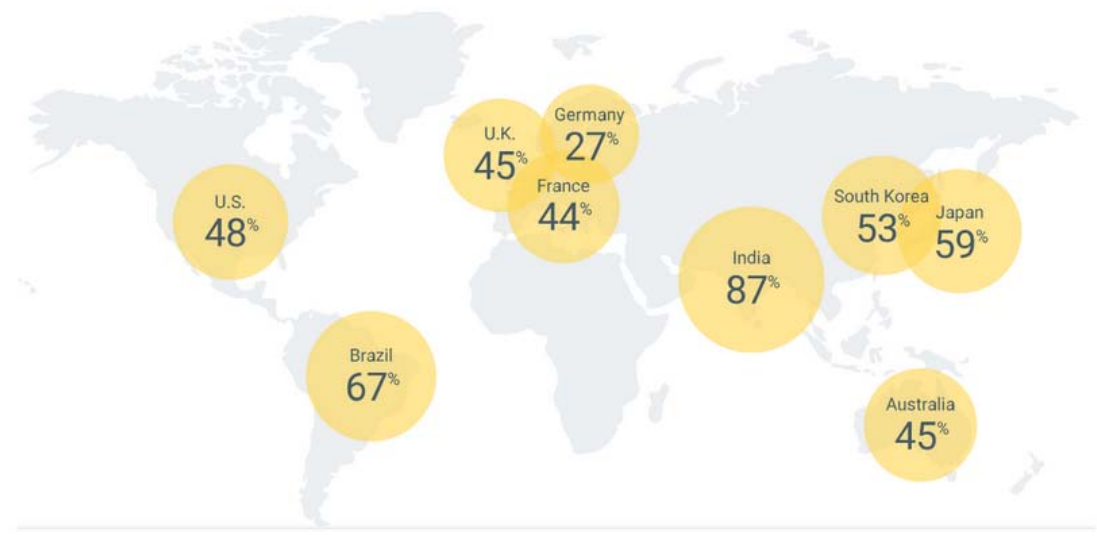

Fig. 1. Booking by Smartphone in 2018

Source: Travel Statistics to Know about in 2018 and 2019, accessed February 27, 2019, https://www.trekksoft.com/en/blog/65-travel-tourism-statistics-for-2019

\section{The Importance of Marketing in Tourism Industry}

A solid marketing strategy is crucial in any business and the tourism industry is no different. [WildWeb, 2019]

Tourism is one of the fastest growing industries in the world and is also one of the best ways to boost a country's economy. With more and more destinations realising this and seeking to attract more tourists, the industry is becoming increasingly competitive. This is why it's now more important than ever to ensure that your marketing strategy is up to scratch. [WildWeb, 2019]

The reasons why a good marketing strategy is vital to the tourism business are [WildWeb, 2019]: 


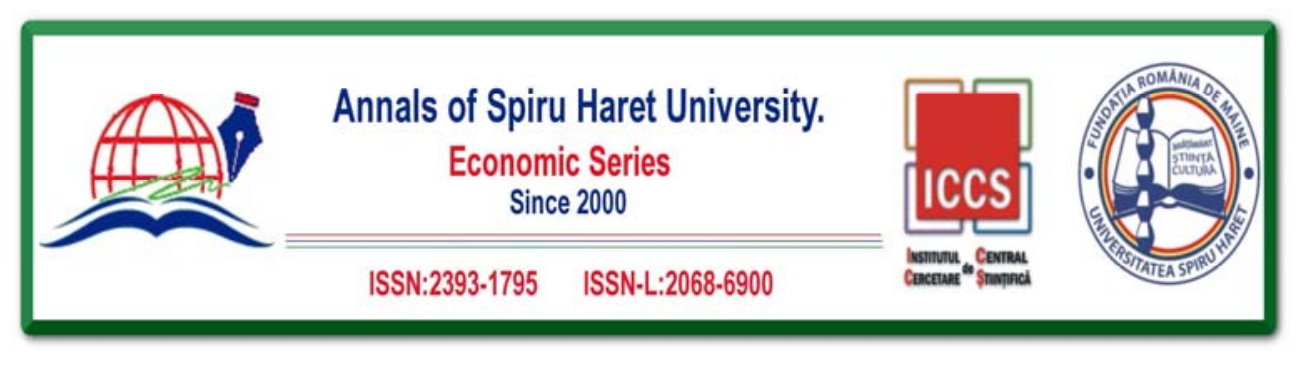

Issue 1/2019

- Identify the ideal target market. The first step to developing a successful marketing campaign is identifying who the ideal target market is. Depending on the experience on offer, the customer will vary.

- Attract new customers and develop loyalty. Once the ideal target market has been identified, a strategy to reach these potential customers must be developed. Because customer loyalty is key, a lot of time needs to be devoted to building brand awareness and creating ongoing, interconnected campaigns that both target previous guests, and attract new ones.

- Understand the customer journey. In tourism, the ultimate end goal is the sale of an experience - not a material object. This means that the customer journey to making a purchase is rather different and comes with its own set of challenges. Understanding this journey that the customer takes before going through with a purchase is critical to a successful marketing campaign.

- Stand out from competitors. As the tourism industry becomes more and more competitive, it's important to make sure that your business stands out. Highlighting what is unique or different about the business is one of the best ways to achieve this. A really good marketing strategy is able to communicate these points effectively to the customers in a way that speaks to them.

- Hone in on the most effective tactics. Using research and analytical tools, a marketing strategy allows you to assess which resources are best helping to reach your audience, and then focus on those resources to ensure the best ROI possible. At the end of the day, having a good marketing strategy in place allows you to feel confident in knowing that all your business's marketing needs are being carefully looked after.

Tourism marketing contributes to the growth of local and national economies worldwide. In fact, one-fifth of all global jobs created over the past decade have been within the travel sector. Nearly 10 percent of all jobs are supported by this industry. [Bizfluent, 2019]

The more people visit a city or country, the more money they spend. This helps grow the local economy and attracts investors. New hotels and vacation resorts open their doors, leading to the creation of new jobs. As the local infrastructure and services improve, the number of tourists increases even more. [Bizfluent, 2019]

Many small cities and towns are home to world-class accommodations. Marketers promote these places online and offline to drive brand awareness and 


\section{Issue 1/2019}

attract visitors. They also make sure that information on restaurants, hotels and other venues is easily accessible and up-to-date. [Bizfluent, 2019]

Tourism marketing drives business growth. If customers are satisfied with your services, they'll spread the world about your facility, whether it's a local pub or a hotel. This will bring you more clients and give you a competitive edge. [Bizfluent, 2019]

Considering these facts, it's no wonder that travel professionals invest billions in marketing. Digital advertising spending in the U.S. travel industry increased from \$2.4 billion in 2011 to $\$ 8.5$ billion in 2018 - and it’s expected to reach $\$ 9.8$ billion in 2019. [Bizfluent, 2019]

Today, you can easily travel from one place to another and use the internet to research every possible destination. [Bizfluent, 2019]

Tourism would not exist to the extent that it does today if tourists are not able to travel from one destination to another, in a quick and efficient manner. [Camilleri, 2017]

Content marketing is increasingly added to the marketing mix of advertising companies in the tourism industry. [TourismReview, 2019]

Creativity in tourism is a central issue, which is set in particular terms in the current period. In essence, creativity in tourism is often measured by the originality of the tourist products offered, by the correspondence between them and the extremely varied preferences of tourists. As a result of the refining of taste and variety of preferences, functionality, correlated with aesthetics, is the essential condition, a demand for the tourist product.

The tourism industry is distinguished by the vast amount of information and data available to target travel enthusiasts. Recovering this data is easy; the real challenge is to analyze these data and draw relevant conclusions from them. Here is the real potential of deep learning. The more data they analyze, the better they will get. The travel sector needs to adapt to the new standards and include a broad view of the user experience.

Many travel companies often focus only on enhancing their performance with retargeting providers. But retargeting also offers them plenty of creative opportunities to successfully promote their brands. 


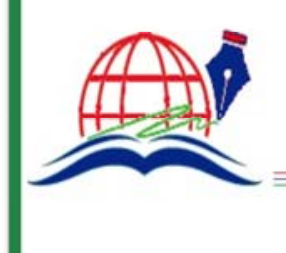

Annals of Spiru Haret University.

Economic Series

Since 2000

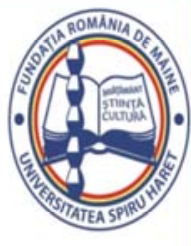

Issue 1/2019

Table 1. Digital Marketing in Tourism Industry

\begin{tabular}{|c|l|c|}
\hline 1. & Hotels which use online marketing & $85 \%$ \\
\hline 2. & Travel agency which use online marketing & $91 \%$ \\
\hline 3. & Small tourism business which use online marketing & $95 \%$ \\
\hline 4. & Travel destinations which use online marketing & $86 \%$ \\
\hline
\end{tabular}

Source: personal contribution

\section{Conclusions}

In conclusion, marketing in tourism is just a way to describe the experiences that potential customers can expect if they buy the respective product.

The stages in marketing strategy are:

-Identify the market customers.

-Transmit information.

-Determine the most appropriate way to reach those costumers.

-Closing the transaction.

-Develop and implement a post-visit strategy.

Marketing strategies depend largely on budget. Marketing means a lot of money spent on a relative percentage of buyers of the tourist product. A marketing strategy focused on a particular market segment, even if it means a higher cost per person, can bring more buyers.

The complexity of the tourism industry, the specific nature of the tourism business's activity bound to take into account all other tourism-related activities, leads to the need for an appropriate marketing approach.

Regardless of the level at which marketing principles apply, the interests involved in tourism activity must be achieved in the spirit of increased responsibility towards society and the environment.

Planning a trip involves the daily visit of hundreds of pages of travel offers and search times that can reach weeks before the final purchase is made. This translates 


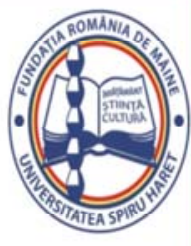

\section{Issue 1/2019}

into a multitude of interactions that Digital Marketing needs to harness. The number of client-to-customer digital interactions increases rapidly as offers returned by search engines, booking applications, online travel agencies, and offers sites get closer to their requirements.

\section{References}

[1] Bizfluent (2019). The Importance of Marketing in Tourism, accessed February 26, 2019, https://bizfluent.com/about-6584954-importance-marketing-tourism.html

[2] Chron (2019). What Is Tourism Marketing?, accessed February 26, 2019, https://smallbusiness. chron.com/tourism-marketing-56473.html

[3] Jabbarov, Fuad (2018). "Implementation of Corporate Governance Mechanisms in Tourism.” Annals of Spiru Haret University. Economic Series, 18(4), 113-122, https://doi.org/10.26458/1846

[4] Gupta, T. C., \& Mirjha, N. D. (2016). "Development of Tourism Industry and Marketing in Chhattisgarh.” Journal of Tourism \& Hospitality, 5:219, https://doi.org/ 10.4172/ 2167-0269.1000219

[5] Kasemsap, Kijpokin (2015). "The Role of Marketing Strategies in the Tourism Industry." Emerging Innovative Marketing Strategies in the Tourism Industry, https://doi.org/10.4018/978-1-4666-8699-1.ch010

[6] Camilleri, Mark (2017). "The Tourism Industry: An Overview." Travel Marketing, Tourism Economics and the Airline Product. An Introduction to Theory and Practice, https://doi.org/10.1007/978-3-319-49849-2_1

[7] Nilead (2019), Digital Marketing in Travel and Tourism Industry, accessed February 27, 2019, https://nilead.com/article/digital-marketing-in-travel-and-tourism-industry

[8] Novelus (2019), Marketing Tourism, accessed February 27, 2019, https://novelus.eu/ industries/tourism-marketing/

[9] TourismReview (2019), The Importance of Content Marketing for Tourism Industry, accessed February 27, 2019, https://www.tourism-review.com/content-marketing-isgrowing-in-importance-news10268

[10] TrekkBlog (2019), Travel Statistics to Know about in 2018 And 2019, accessed February 27, 2019, https://www.trekksoft.com/en/blog/65-travel-tourism-statistics-for2019

[11] Yeh, Tsu-Ming, Chen, Shun-Hsing, \& Chen, Tsen-Fei (2019). "The Relationships among Experiential Marketing, Service Innovation, and Customer Satisfaction - A Case Study of Tourism Factories in Taiwan.” Sustainability, MDPI, Open Access Journal, vol. 11(4), pp 1-12, February, https://doi.org/10.3390/su11041041 


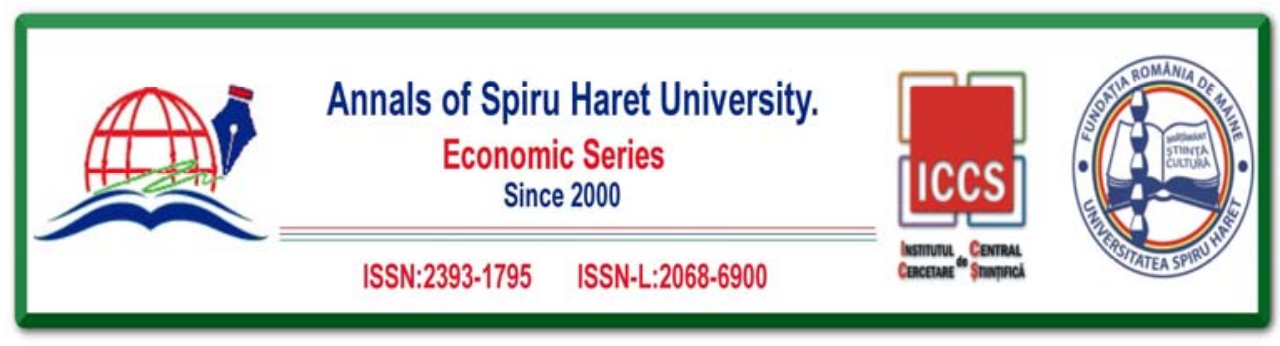

Issue 1/2019

[12] WildWeb (2019), The Importance of Tourism Marketing, accessed February 26, 2019, https://www.wildweb.co.za/blog/the-importance-of-tourism-marketing/

[13] Alhawamdeh, Zead M. (2019). "The implementation of the Marketing Communication Mix using Internet Platforms on Turkish Cypriot Hotels." International Journal of Business and Management, Vol. 14, No. 3, https://doi.org/10.5539/ijbm.v14n3p124 
